\title{
Workplace Romance 2.0: Developing a Communication Ethics Model to Address Potential Sexual Harassment from Inappropriate Social Media Contacts Between Coworkers
}

\author{
Lisa A. Mainiero \\ Fairfield University, Imainiero@fairfield.edu \\ Kevin J. Jones
}

Follow this and additional works at: https://digitalcommons.fairfield.edu/business-facultypubs Copyright 2013 Springer, Verlag - Journal of Business Ethics

\section{Peer Reviewed}

\section{Repository Citation}

Mainiero, Lisa A. and Jones, Kevin J., "Workplace Romance 2.0: Developing a Communication Ethics Model to Address Potential Sexual Harassment from Inappropriate Social Media Contacts Between Coworkers" (2013). Business Faculty Publications. 134.

https://digitalcommons.fairfield.edu/business-facultypubs/134

\section{Published Citation}

Mainiero, Lisa A., and Kevin J. Jones. (2013). "Workplace Romance 2.0: Developing a Communication Ethics Model to Address Potential Sexual Harassment from Inappropriate Social Media Contacts Between Coworkers." Journal of business ethics 114(2), pp. 367-379

This item has been accepted for inclusion in DigitalCommons@Fairfield by an authorized administrator of DigitalCommons@Fairfield. It is brought to you by DigitalCommons@Fairfield with permission from the rightsholder(s) and is protected by copyright and/or related rights. You are free to use this item in any way that is permitted by the copyright and related rights legislation that applies to your use. For other uses, you need to obtain permission from the rights-holder(s) directly, unless additional rights are indicated by a Creative Commons license in the record and/or on the work itself. For more information, please contact digitalcommons@fairfield.edu. 


\title{
Workplace Romance 2.0: Developing a Communication Ethics Model to Address Potential Sexual Harassment from Inappropriate Social Media Contacts Between Coworkers
}

\author{
Lisa A. Mainiero • Kevin J. Jones
}

Received: 29 September 2011 / Accepted: 4 May 2012/Published online: 29 May 2012

(C) Springer Science+Business Media B.V. 2012

\begin{abstract}
This article examines ethical implications from workplace romances that may subsequently turn into sexual harassment through the use of social media technologies, such as YouTube, Facebook, LinkedIn, Twitter, text messaging, IMing, and other forms of digital communication between office colleagues. We examine common ethical models such as Jones (Acad Manag Rev 16:366-395, 1991) issue-contingent decision-making model, Rest's (Moral development: Advances in research and theory, 1986) Stages of Ethical Decision-Making model, and Pierce and Aguinis's (J Org Behav 26(6):727-732,2005) review of workplace romance versus sexual harassment issues. The article makes a contribution by developing a new communication ethics model that includes response positive and response negative contingencies to guide decision-making about inappropriate social media contacts that spillover into the workplace. In addition, we recommend that human resource personnel take a more active role in communicating appropriate ethical rules of conduct concerning the use of social media technologies inside and outside the office.
\end{abstract}

Office/workplace romance scenarios offered in this document are examples drawn from known situations associated with reports given to the authors, but are to be considered fictitious for purposes of illustration except where specified within. The cases included both men and women in various scenarios to respect gender neutrality.

\section{A. Mainiero}

Fairfield University, Fairfield, CT, USA

e-mail: 1mainiero@fairfield.edu

\section{K. J. Jones $(\bowtie)$}

Indiana University-Purdue University Columbus,

Columbus, IN, USA

e-mail: joneskj@iupuc.edu
Keywords Business ethics - Communication ethics · Facebook - Human resource codes of conduct - Human resource guidelines · LinkedIn - Office romance $\cdot$ Sexual harassment · Social media technologies · Twitter · Tumblr · Workplace romance

\section{Introduction}

Workplace romance and its sometimes related twin construct, sexual harassment, are pervasive in organizational life. For example, Vault.com's 2010 office romance survey found that $60 \%$ of workers participated in some kind of workplace romance and $64 \%$ said they would participate in another one (www.vault.com/officeromancesurvey.) One in five employees admitted a relationship with a boss, and $15 \%$ said they have had a relationship with someone they supervised. Once considered taboo and private, according to a 2009 Career Builder survey (www.shrm.com) the majority of workplace romances are openly pursued. A 2010 survey by Monster.com (2010) reported $21 \%$ of those surveyed would consider dating a coworker in their department, while $48 \%$ would consider dating a coworker in another department (www.monster.com/romance.)

Known romantic liaisons can have both positive and negative outcomes such as increased job involvement, engagement, and work motivation among romance participants yet at the same time decrease work group morale (Mainiero 1989; Pierce 1998; Pierce et al. 1996; Pierce and Aguinis 2001; Powell and Foley 1998), especially when a hierarchal romance between a boss and a direct report is involved (Anderson and Hunsaker 1985; Mainiero 1986, 1989, 2005; Pierce 1998; Quinn 1977.) Boyd (2010) recently reviewed the issues associated with organizational policies prohibiting workplace romances, and concluded 
that a ban on office romance is antisocial as well as impractical.

However, according to a Society of Human Resource Management (SHRM) 2006 survey, $77 \%$ of human resource professionals said the fear of sexual harassment claims was a reason to discourage workplace romance and $67 \%$ had concerns about retaliation post-romance (SHRM 2006, survey on workplace romance.) Sexual harassment at work has many negative outcomes, such as decreased job productivity, increased stress, absenteeism and tardiness, and turnover (Gutek 1985; Pierce and Aguinis 2001; O'LearyKelly and Bowes-Sperry 2001; O'Leary-Kelly et al. 2009; Schneider et al. 1997; Terpstra and Baker 1992.) The legal definition of sexual harassment as a construct entails two forms: (1) Quid pro quo (QPQ) sexual harassment, involving threats to make employment-related decisions such as hiring, promotion, termination on the basis of target compliance, and (2) Hostile work environment (HWE) sexual harassment, defined as sex-related conduct that unreasonably interferes with an individual's work performance or creates an intimidating, hostile, or offensive working environment (O'Leary-Kelly et al. 2009.) According to the EEOC (the Equal Employment Opportunity Commission), money paid out by companies in sexual harassment lawsuits has averaged $\$ 47.8$ million over the past 12 years and there has been an additional recovery of $\$ 376$ million on behalf of discrimination victims in 2009 (EEOC Annual Report, 2010.)

The use of new social media technologies such as Facebook, LinkedIn, and Twitter, as well as Foursquare, internet blogs, and instant text messaging on iPhones, Droids, Blackberrys and other personal communication devices have created situations where some employees complain another employee may have created a hostile work environment for them outside the office which then impacts their behavior inside the office. In this new day and age of social networking, friending a coworker on Facebook or allowing the release of one's personal cell phone number as a result of a personal romantic relationship may be fine initially but may turn to harassment or stalking behavior once the relationship has ended. Even though such social media contacts take place outside the office, employees may feel uncomfortable returning to the office to continue working with a former paramour in a decision meeting on critical work information. For example, coworkers who had previously dated broke off the dating relationship. Even though both agreed the dating relationship had ended, they agreed to remain friends. Unfortunately, problems began when one partner continued to want to know personal details about the former dating partner's daily activities by texting questions such as who are you going to lunch with? and what time are you leaving work? Both soon became uncomfortable seeing and working with each other and the tension between the two became obvious to coworkers adversely affected work team outcomes.
This article details: (1) the complications associated with digital media communications that blur the lines between workplace romance and sexual harassment, (2) the necessity of careful communication between coworkers that is not subject to misunderstanding, and (3) a communication ethics model to guide human resource professionals in the training of employees concerning appropriate use of social media technologies that cross personal and professional lines. The article further raises the question whether an employee can be or should be held professionally responsible for what they put on the internet, and whether or not employers should intervene in workplace affairs that cross personal and professional lines.

\section{Case Scenario \#1}

Consider the following scenario: A woman, a new recruit to an accounting firm, engages in conversation with another recruit, a man. They find they work long hours together on a compelling job assignment that might take them to an exciting foreign location. As they obtain their airline tickets, the woman shares her cell phone number with the man so they could find seats together on the plane. They have an animated discussion on the airplane that covers many common personal topics. In the foreign location, they embark on a romance that lasts two months. They part ways, initially amicably, but when they return from their global assignment, he continues to text her on her phone, asking for frequent lunch meetings so they can talk. He writes provocative commentary on her Facebook page and recommends her work on LinkedIn. Eventually she blocks him from her Facebook page, yet he still has memorized her cell phone number and continues to text her during the day and evening hours. Before lunch each day, he checks her whereabouts on Foursquare, making her feel that he is stalking her at lunchtime. At work, they are assigned a similar departmental project that requires frequent meetings. During meetings, he finds a seat directly next to her to grab her hand under the table or brush against her thighs. He emails constant love notes. Annoyed, the woman wonders if she should take the situation to Human Resources_-or not, as she was once a willing participant in the romance.

Given that social media blurs personal and work contacts, it is difficult to discern where to draw the line between romance and harassment. In this scenario, both participants willingly engaged in a voluntary romance. When the romance ended, social media allowed for continued contact outside of the office that has a harassing tint. Yet in the office, both participants must continue as professional colleagues on a mutual project. Should the woman go to the Human Resource department and ask for protection, as the man is harassing her outside of the office 
post-romance? What are the ethics of this situation, as it borders on sexual harassment but may not meet the criterion of such?

Workplace law has not yet caught up with such incidents to define parameters for consideration.

Cases in the courts tend to focus on aspects of sexual discrimination, such as: (1) the denial of a promotion as a result of an office romance, or (2) the severity of a hostile work environment created by one. For example, Jones v Keith (2002) and McDonough v Smith (2001) supported claims of sexual harassment resulting from a previously dissolved workplace romance. King v Palmer (1986) claimed sex discrimination when King was unlawfully denied a promotion to a supervisory position when it was awarded to another nurse romantically involved with a higher up. Broderick v Ruder (1989), Proxel v Gattis (1996) and Miller and Mackey $\mathrm{v}$ The California Department of Corrections (2005) were cases that substantiated a hostile work environment as a result of one or more office affairs between employees with supervisors that awarded claims to employee plaintiffs, most notably the latter which set a new standard for third party claims in California. Note that none of these cases examined sexual harassment through social media contacts outside the workplace; each case subscribed evidence to work office behaviors to support resulting claims of discrimination or hostility. Many of these cases, however, concerned an ongoing workplace office affair that had consequences for other parties or a dissolved workplace romance that later resulted in claims of sexual harassment.

Pierce et al. (2004) performed a content analysis specifically on legal cases of romances that dissolved into sexual harassment. The authors found that while judges' decisions can be predicted from legal case features in accordance with a legal standard, investigators reviewing the same cases followed an ethical model that incorporated factors outside of the law. For example, judges were concerned whether witnesses were involved, and examined evidence relating to the case. Investigators focused on other relevant workplace related factors, such as the frequency of harassment, the status of the alleged harasser, gender roles, and the job-related consequences of harassment.

The problem here is that situations such as the previous scenario are not directly illegal and would not necessarily hold up in a court of law according to the legal definition of sexual harassment under the hostile work environment standard. Much of the continued contact occurs through social media outside of the eyes and ears of colleagues in the office. Yet the woman in the scenario feels distinctly uncomfortable and experiences a hostile work environment as she is not in agreement with his continued actions. While not directly illegal, the situation requires an ethical model so that Human Resources can identify ways in which to intervene in the situation should the situation escalate. What the man is doing is not necessarily illegal but is unethical by most standards, and the woman feels uncomfortable in her work environment. When office decorum is disrupted by a failed office romance, we believe it becomes the firm's responsibility to act to protect the employee who no longer desires the office romance and co-workers who inadvertently have become part of the office romance drama.

\section{The Ethics of Workplace Romance and the Role of Moral Intensity}

Because workplace romances cross boundaries of office protocol and decorum, they have been subjected to intense legal and ethical scrutiny. This subject, a nexus between personal and professional roles, also has attracted the theoretical ethical attention of organizational scholars, several of whom have published in the Journal of Business Ethics (Argandona 2011; Boyd 2010; Devine and Markiewicz 1990; McDonald and Pak 1996.) The most frequent ethical model applied to workplace romance is that of Jones (1991) model of moral intensity as an important determinant of individual's ethical decision-making. He suggested that moral intensity should be conceptualized as a multidimensional construct with six components: (1) social consensus, the degree of social agreement that an act is evil or good, (2) proximity, the feeling of nearness for beneficiaries or victims of the act, (3) magnitude of consequences, defined as the harm or benefit done to beneficiaries or victims of the act, (4) concentration of effect, an inverse function of the number of people affected by an act of a given magnitude, (5) probability of effect, defined as a joint function of the probability that the act will actually occur and that it will cause anticipated harm or benefit, and (6) temporary immediacy, conceptualized as the length of time between the present and the onset of consequences of the act.

High moral intensity would meet a combination of several of the above criteria; lower moral intensity would not merit immediate action or intervention. According to Jones (1991), when individuals are confronted with an issue that is higher in moral intensity, they are more likely to progress through the stages of ethical decision- making described by Rest (1986):

Stage One: Recognizing the issue as a moral or ethical one;

Stage Two: Making a moral judgment regarding the issue;

Stage Three: Establishing intentions to behave in accordance with that moral judgment; and

Stage Four: Engaging in moral or ethical behavior. 
Jones's model is issue-contingent; it involves assessing an issue at hand and developing ethical principles in accordance with that issue. Jones and Ryan (1998) contend that organizational factors affect moral judgment and subsequent moral behavior. Morris and McDonald (1995) examined the effect of moral intensity on ethical decisionmaking following this model and Kelley and Elm (2001) revised Jones's model to include elements of the context, such as organizational factors involving group dynamics, authority factors, and socialization processes that might influence managers' experience of ethical issues.

Bowes-Sperry and Powell (1999) proposed and tested Jones's model as a way of conceptualizing individual's reactions to social-sexual behavior at work, and found that the ethical ideology of the observer dictated their recognition of the behavior as an ethical issue. The authors examined the effect of three components of moral intensity: (1) social consensus, (2) the magnitude of consequences, and (3) proximity. Two components of the moral intensity of the behavior-social consensus and magnitude of consequences-directly influenced observer's reactions. When observers witnessed behavior by the initiator that appeared to have a greater effect on the target, and when also they believed that most people would regard the behavior as sexual harassment, they were more likely to recognize the behavior as an ethical issue and to establish intentions to intervene in the behavior.

To take the widely publicized case of Congressman Anthony Weiner's 2011 Twitter posts as an example of social media technology crossover into harassment, there was a general social consensus purported by the media that sending pornographic photos over the internet to women, and also following those women on Twitter, was inappropriate behavior that was ethically and morally wrong (Parker-Pope 2011.) In addition, members of Congress realized an ethics investigation would be called in Congress to investigate Congressman Weiner's internet communications to constituents possibly requiring him to leave his post. Taken together, the moral intensity of the issue was high given his role as a representative to Congress and how his behavior reflected on that August body. While sexting is commonplace among individuals in society (Lenhardt et al. 2010), his actions seemed unbecoming of a Congressman's role, and he was asked to resign his post. Companies may take a similar ethical stance should an employee be discovered to be cyberstalking or issuing inappropriate photos or comments to another employee.

Pierce et al. (2004) also provided preliminary support for Jones' (1991) issue-contingent model and extended it further as an explanation for the underlying social-cognitive process through which investigators make decisions in response to sexual harassment that stems from a dissolved workplace romance. Subjects reading vignettes about different romance cases rated individuals in direct reporting relationships as more responsible for their actions, and raters who judged the accused as responsible for harassing behavior reported that it was more appropriate to discipline the accused. The degree to which investigators recognized a dissolved workplace romance/sexual harassment scenario as unethical varied as a function of features of the romance (e.g., whether it was non-extramarital or extramarital), features of the harassment (e.g., whether it was a hostile work environment or quid pro quo), and features of the organization (e.g., whether or not it had a policy prohibiting workplace romances and if it had been effectively communicated). The authors also found that investigator's degree of recognition of the romance-harassment scenario as unethical varied despite their evaluations of the accused social-sexual conduct as constituting sexual harassment. This finding held for male and female investigators as well as for both types of harassment scenarios.

\section{Case Scenario \#2}

As an example, consider the following office romance/ harassment scenario. Two employees, a male and a female, embarked on an office romance in a firm that encourages people to meet and fall in love at work. The female in this case was the direct reporting boss of the male subordinate, and they worked in the same department. At the time of the liaison, the man was married. The affair ran more than two years. The couple frequently texted each other for trysts outside the office and at one point joined the website www.AshleyMadison.com , a known haven for extramarital liaisons. Eventually the male employee was promoted to another departmental manager position, becoming a peer relation to the female boss. He then became involved with another female employee who worked for the company in another department. The original paramour heard of the liaison, and became upset by the news. She then friended the new paramour on Facebook, and then engaged in a social media campaign on Facebook and Twitter to smear her former lover, and wrote salacious details about her affair with the man on Tumblr. Conflict at the office became heated when a visible verbal fight between the two women broke out in the company cafeteria over the Facebook and Tumblr commentary.

One could imagine how human resource professionals would react to this scenario. On the one hand, this scenario involves consensual romantic relationships at work, and it is no business of the firm to legislate extramarital affairs outside of the office. On the other hand, one employee is harassing another on social media as a result of her personal romantic liaison. There is a spillover impact that affects the workplace. No promotions were offered, no undue favors or obligations created, nor were rules of the office broken. Nothing 
(technically) illegal happened according to the standards of law. Yet hostility ensued in the workplace environment over a dissolved office romance. According to the Pierce et al. (2004) framework, investigators would consider several factors before taking action in this situation: the extramarital affair, the hostile work environment visibly witnessed in the company cafeteria, and attitudes of members of the firm toward office liaisons. Human resource professionals would need to decide to intervene in this situation on the basis of whether workplace norms were disrupted, and whether or not the social media actions constitute a form of harassment.

O'Leary-Kelly and Bowes-Sperry (2001) contend that sexual harassment may occur less frequently if awareness is heightened such that actors are encouraged to regard sexually harassing behavior as involving a moral component. Research shows that the most common response to a sexual harassment incident is avoidance/denial (Baker et al. 1990; Hotelling 1991; Knapp et al. 1997.) According to O'Leary-Kelly and Bowes-Sperry (2001), behaviors in this category include: avoiding the harasser, ignoring the behavior, going along with the offending behavior, selfblame, and treating the behavior as a joke (Knapp et al. 1997.) In fact, reporting of sexual harassment can be conceptualized as a form of whistle-blowing behavior, for which individuals could face significant penalties (Miceli and Near 1992.) Bowes-Sperry and Powell (1999) also found that observers of sexual harassment are less likely to perceive an initiator's behavior as an ethical issue or to state that they will intervene in an incident of harassment when the target does not appear to be upset by the behavior than when she does.

Pierce and Aguinis (2001) have studied the distinction between workplace romances and sexually harassing behavior, such that the motives of the couple, whether it be a love match, a fling, a utilitarian relationship, or a mutual user relationship, predicts the perception of whether or not the dissolution of the romance can be defined later as harassment. They theorized that the organization's tolerance for sexual harassment (low, high), moderated by several variables such as: (1) partner's social power, (2) whether the romantic relationship was dissolved mutually or by one participant, (3) the sexual harassment proclivity of the male partner (low, high) and (4) the nature of residual affect lead to defining the later post-romance behavior as sexual harassment. Pierce et al. (2004) further clarified these original results by examining whether or not gender, supervisory relationship, the type of romance, and other variables affected rater's perceptions of moral responsibility in a dissolved office romance. The illicitness of the romance (extramarital vs. singles), the presence of a romance policy in the firm, and the type of harassing behavior defined whether or not raters recognized the harassing behavior as immoral, requiring discipline or not. In the case of the above scenario, all of these variables would be evaluated to determine disciplinary actions, if any.

\section{A Matter of Ethics-Communication Ethics}

Because social media allows for alternate communication channel(s) in and outside of the workplace), the possibility that one party may receive unwelcome romantic or sexual messages complicates matters beyond the legal standard. According to the Society of Human Resource Management, $24 \%$ of 466 human resource professionals and $31 \%$ of employees reported that sexual harassment claims occurred in their organizations as a direct result of workplace romances (SHRM 2002, survey on workplace romance.) It is important to note that workplace romances do have positive outcomes, sometimes resulting in marriage or committed partnerships that are approved by coworkers in the office (Mainiero 1989; Pierce 1998; Pierce and Aguinis 1997), and according to a recent survey by Career Builder.com, 4 out of 10 coworkers say they have dated a colleague at some point in their careers, and 3 in 10 say they married the person they dated at work. According to Boyd (2010), the incidence of sexual harassment is very low in comparison to the number of long term relationships initiated in the workplace. As many situations may not officially cross into the legal definition of sexual harassment, it is important to define an ethical model to represent what is appropriate and inappropriate workplace behavior when romance is concerned.

\section{Case Scenario \#3}

Consider the following scenario: A woman sees an attractive coworker in another department. She wants to communicate her interest in him and discover whether or not he might be interested in meeting outside the office. She waits in the lobby each day and watches him leave the building. One day she notes that her coworker goes into a local bar down the street. She follows him into the bar, and engages him in office conversation. They part having shared cell phone numbers and stories about work colleagues. That night, she wonders if she should communicate her romantic interest further by sending a text to his cell phone. She does not want to exhibit behavior that would jeopardize their future work relationship, but she felt her coworker seemed friendly and would welcome further interaction. That night, she decides to friend him on Facebook, and checks out his profile on LinkedIn before deciding if she should communicate with him further to gauge his potential romantic interest.

Communication is a representational device enabling expression of internal feelings (Baxter and Akkoor 2008). 
Fig. 1 Communication ethics model of workplace romance
Communication Ethics Model of Workplace Romance, K. Jones and L. Mainiero, 2011 (Based on the Issue-Contingent Model of Ethical Decision Making in Organizations, Jones, 1991)

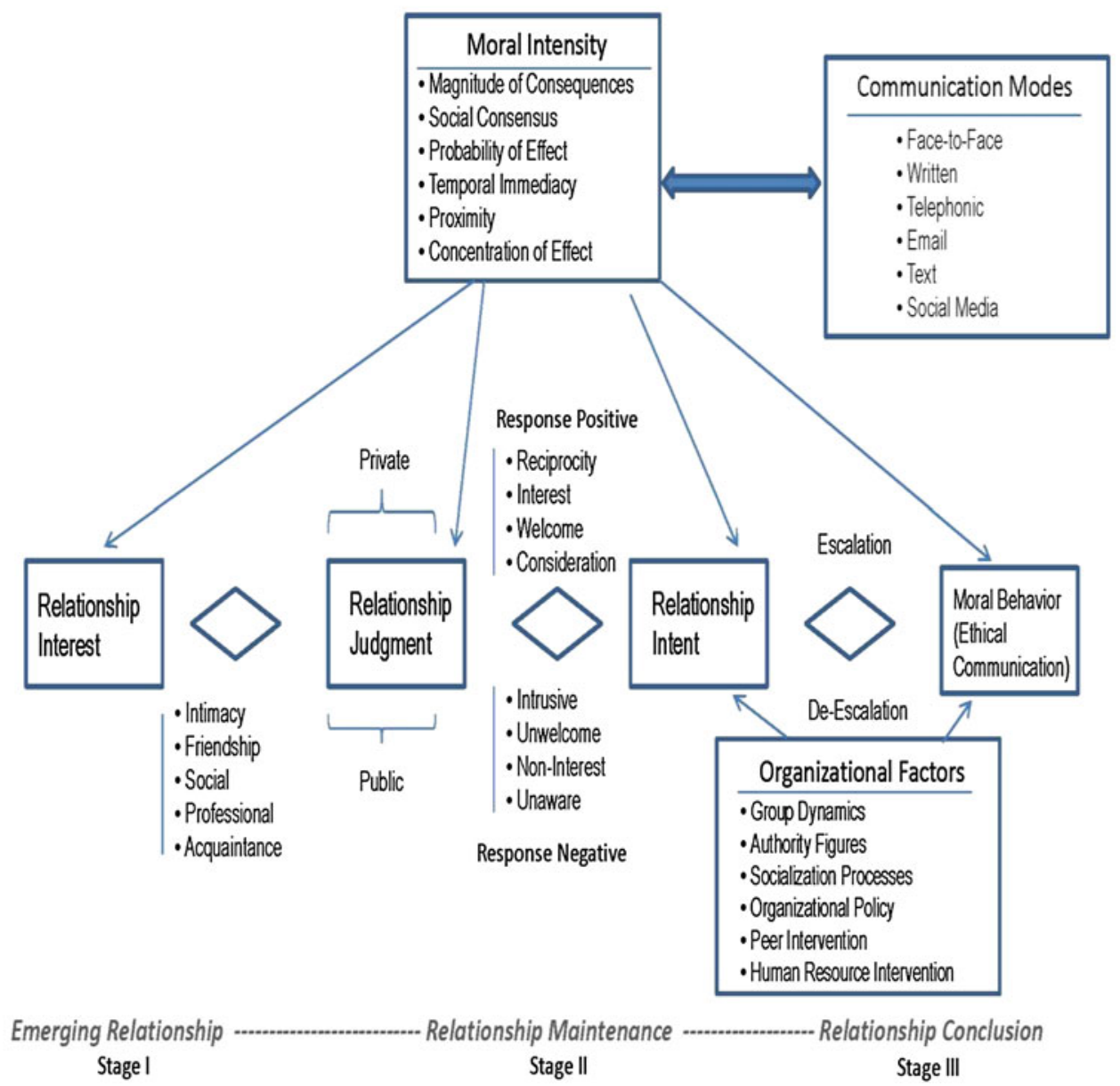

Communication ethics may guide one's perceptions of truth, deception, openness, secrecy, disclosure, conflict and more (Littlejohn and Foss 2009; Cheney et al. 2011). Neher and Sandin (2007) define communication ethics as the application of ethical thinking to situations involving human communication. Humans perceive connection and inclusion as basic human rights (Planalp and Fitness 2011) and this connection and inclusion is accomplished through communication.

Questions of communication ethics emerge in the areas of interpersonal, organizational, cultural, and mediated contexts (Stewart 2011; Littlejohn and Foss 2009). Communication ethics may govern the discourse concerning what is said, when it is said, how it is said and with whom it is said. Communication ethics may also govern the nonverbal communication messages ranging from preferred personal space to the chosen apparel of a person. Since communication involves possible influence, considers choice toward a specific ends, and employs the means to accomplish the ends, it can be judged from an ethical perspective (Johannesen 2002). Communication ethics encompasses communication in mediated contexts where the effects of digital technologies create additional ethical issues and challenges (Ess 2011).

Given the prevalence of workplace romance, and the fears of human resource professionals that undiscovered romances will turn into harassment, it is important to define an ethical model to represent what is appropriate and inappropriate workplace behavior when romance is concerned. This model is intended to guide behavior that represents the gray area-romantic communications that escape the direct legal standard of harassment (which would require organizational action) but nonetheless are perceived as bothersome or intrusive to an employee in or outside the office. We have constructed a model (Fig. 1), the Communication Ethics Model of Workplace Romance to guide organizational members to consider the communication ethics of their workplace romance actions. The model is based on the Rest (1986) Ethical Decision-Making Model and the Jones (1991) Issue-Contingent Model of Ethical Decision-Making. The Communication Ethics Model of Workplace Romance can be described as an 
ethical issues-contingent model focused on the context of organizational workplace relationships. The model specifically addresses communication ethics concerns that emerge from workplace relationships and suggests a communication dialog for intervention by observers of the relationship, such as human resources personnel.

This focus on communication ethics enables organizational members to: (1) assess one's personal perspective regarding a workplace romance and (2) remember the person of interest's perspective in the interaction. The Communication Ethics Model of Workplace Romance is $h$ elpful in clarifying appropriate behavior consistent with the corporate code of conduct, encouraging open discussion between involved parties, and representing a thought process by which human resource professionals can take action concerning behavior that exceeds the gray area of propriety and potentially could be considered sexual harassment. In addition, a communications ethics model allows exploration of the appropriateness of messages internal to the romance through use of digital communications and social media technologies used to initiate and maintain the romance in an office setting, where work roles and personal boundaries may become blurred. To this end, we demonstrate the model application through the use of scenarios that cover the initiation of an emergent romance, its maintenance in the office setting, and its conclusion.

\section{Communication Ethics Concerning the Internal Romantic Relationship of the Couple}

The model begins with one's Relationship Interest, based on the Jones (1991) concept of Moral Interest. The Relationship Interest stage involves thinking through the decisions and actions that may proceed from one's romantic interest in another individual at work. This stage requires a consideration of the outcomes (intimacy, friendship, social, professional, acquaintance) that can emerge from communicating interest which are influenced by the potential outcome of the dialog. While the desired outcome may be intimacy, this may not always be possible or welcome. This stage requires that the interested party considers a variety of modes of communication, including digital communication technologies to express interest. Modes of communication might include a casual conversation in the office, a request for a cell phone number, or a friend request on Facebook. In the case scenario about the woman interested in her male colleague, she chooses to meet him in person at the bar, and then follows up with a friend request on Facebook while reading his LinkedIn profile before she initiates further communication via text messaging. She combs Facebook for pictures of a girlfriend, but concludes he is currently single.
Once communication is initiated, the party will need to make a Relationship Judgment, based on the Rest (1986) and Jones (1991) concept of Moral Judgment. The person who has expressed interest must consider whether the communication was responded to either positively or negatively. Ideally, one's communication actions are received with a response positive. This would assume some reciprocity of the interest, welcoming further communication dialog. It is also at this stage it is determined whether further private communication or public communication will best serve the emerging relationship. It should be noted that if a relationship entreaty is met with a response negative ranging from unawareness of romantic interest (e.g., we're just friends) to the perception of intrusive interest (e.g. never bother me again), a judgment must be made about the actions to communicate interest. This is where the digital technologies blur the lines of ethics. One may not understand that a text may be considered response negative or a poke on Facebook may be considered intrusive. The challenge for the interested party is: (1) to think through whether the message conveyed using a digital communication mode will enable or hinder the message to be understood as intended and (2) understand in a meaningful way the response that is received and the intent behind the message. The woman in the scenario has several choices. She can wait to meet her romantic interest in person at the company cafeteria to gauge further interest or she can attempt to communicate with him through digital means on Facebook, LinkedIn, Twitter, or other platforms. If the coworker responds to her texts in the affirmative, then she can consider moving the relationship forward into a possible meeting. If she receives feedback that is cursory or lacking in attention, she may realize that the gentleman is not interested in a romantic entanglement, and instead focus on preserving the work relationship.

Relationship Intent is based on the Jones (1991) conceptualization of Moral Intent. This stage should inform the romantic relationship seeker as to whether one's intent should be pursued or move toward a different state. The assumption here is that one's intent should not be to create a negative relationship but a positive relationship ideally resulting in a romantic relationship. This would involve a reflection on the types of communication modes chosen to consider interest and the subsequent responses, positive or negative. For example sexting a picture of oneself to someone who has not expressed a response positive to one's communication may result in an adverse outcome and possible legal implications. Because work roles and personal roles can become blurred in an office setting, it is critical that the woman in this scenario directly communicate (preferably in person) to the coworker that she has a romantic interest. Otherwise, messages may be confused and the coworker may perceive her use of social media 
technologies as intrusive. To avoid potential problems, her intent must be made clear by choosing the most effective mode to communicate her interest.

Moral Behavior (i.e., Ethical Communication) is based on the Jones (1991) and Rest (1986) Moral Behavior conception. The interested party has received a response that is positive or negative. At this point, a decision is made to continue romantic communication or cease communication of a romantic nature and return to business professional roles. Moral Intensity and Organizational Factors (see Jones 1991) further influence the ethical decision-making process (Kelley and Elm 2001; McMahon and Harvey 2006) at this point in the emerging relationship. In the Communication Ethics Model of Workplace Romance, these factors operate to effect the decisions made to communicate interest, the mode of communication selected and the decision to continue or cease communication based on how others may perceive the romance in the organizational setting. Factors such as group dynamics, authority figures, socialization processes, organizational policies, peer intervention, and the possibility of human resource intervention may be considered. If the coworker in the previous scenario balks at the idea of a possible romantic entanglement, saying that he is not interested in dating someone in the same office, ethically the woman should cease and desist any further use of social media technologies to communicate romantic interest and only use these technologies as required to perform work roles when communicating with the noninterested in romance colleague.

The stage of the romantic relationship also is included in this model. Ethical concerns associated with workplace romances include aspects associated with initiating, maintaining, and concluding a workplace romance, and also a separate decision about whether or not to take a romance public. When initiating a romance in the Emergent Relationship Stage (Stage I), communication ethics may dictate which mode of communication should be used to initiate a potential workplace romance. In workplace romances, the way one communicates signals one's interest or lack of interest in pursuing an office romance. Recognizing in the discourse whether an interest is welcomed or unwelcomed and respecting the other's stated interest is a communication ethics issue. For example, complementing the appearance of another and sustaining eye-contact with the person of interest may be appropriate for the ethics of a club but may not be perceived as appropriate in certain organizational climates. Using emoticons of a happy face winking may be appropriate between college friends but not between a boss and a direct report on an email message. Individually, communication ethical principles may vary (what is right for one may be wrong for another), creating potential for of misunderstanding. In the worst case, a winking emoticon could be perceived as harassment. In the scenario of the woman and her hoped for romance with a coworker, she must respect the other party's lack of interest and move on. Any other use of digital communications for personal reasons would be considered ethically and organizationally inappropriate or create a misunderstanding that could lead to perceived stalking behavior.

Maintaining a relationship in the Relationship Maintenance Stage (Stage II) through comments such as I love you or I'm thinking about you are typical relationship communications. Digital technologies enable these messages of relationship maintenance to supplement and/or replace the verbal communication with a text message, email or social media post. At what point, however, does digital communication fall into the relationship maintenance category or become intrusive and unwelcomed in the workplace? Let's pursue this scenario further for purposes of illustration. Perhaps the male coworker may have not had romantic interest in the woman initially as he had a girlfriend outside the office, but that relationship dissolved and now he is available for a new relationship. He pursues the coworker and indicates his interest and availability. The two colleagues embark on a romantic liaison. Unfortunately, he uses digital communications profusely while engaging in the new relationship, texting her every hour on the hour while she is working in the office. She starts to feel smothered by the continuous stream of messages such as I can't get enough of you and I think of you every moment. Continuous texts make the woman feel uncomfortable, and the use of Foursquare during lunch to pinpoint her location is seen as unwelcome. In this case, dissonance between the two parties can emerge, and perceptions of an unwelcome or hostile work environment may emerge requiring organizational action to resolve concerns. To avoid this adverse situation, it is critical that each party respects communication signals that suggest response positive or response negative behaviors.

Finalizing a relationship in the Relationship Conclusion Stage (Stage III) is difficult under the best of circumstances. Clear communication boundaries must be established so that neither party feels offended or intruded upon. When the relationship reaches a conclusion, both parties must be taught to respect each other's workplace boundaries and avoid using digital technologies to send covert messages that would be perceived as unwelcome or negative. Defining what is response positive from a communication perspective (perhaps, a meeting for coffee after work hours) versus what is response negative (don't contact me on Facebook) is critical to maintain stability of the work relationship once the personal relationship is dissolved. 


\section{Case Scenario \#4}

Consider yet another scenario based on an ongoing romance in the office. A woman and a man developed an office romance that is known to many others in the office. However, the woman became uncomfortable in the romantic relationship after the man was promoted, fearing he was in a position to influence her career. While the relationship was romantic, both texted each other each day in the office and were regulars on each other's Facebook and Twitter profiles. They used Foursquare to identify each other's locations. However, once the relationship hits a snag, the woman became uncomfortable when the man posts messages on her Facebook profile publically that other coworkers can read and discover. Should a relationship breakup occur, the woman ethically must provide a response negative communication message and clarify that she no longer wants him to text, message, post comments on Facebook, or follow her on Foursquare, Twitter or her internet blog unless the communication specifically is work-related. She has an ethical imperative to communicate clearly her boundaries on the matter; he has an ethical imperative to cease and desist using social media as a covert method to contact her to continue to pursue the relationship.

A significant issue is that workplace romances become public as co-workers tend to discover these relationships (Sias 2009). Despite the reality that workplace romances are discoverable and information is disseminated as rumor and gossip (Michelson and Mouly 2002), couples often desire for the relationship to be private. The desire to keep the relationship private may lead to communication to hide the relationship or deny the relationship. Lying along with intentional ambiguity and vagueness is a significant communication ethics issue (Johannesen et al. 2008) as it can erode the trust necessary to sustain an effective interpersonal relationship (Neher and Sandin 2007). The attempt to obfuscate a workplace romance may seem justifiable and pragmatic to the couple but may lead to questionable ethical communication choices to keep the relationship private. Attempting to keep a workplace romance private despite potential discovery in social media raises issues about openness, honesty and trust. Stated another way, communication used to hide or deny a workplace romance can result in diminishing the credibility of the communicator and raise questions about the integrity of the romance participants.

One goal of this model is to examine the stages of the relationship and frame it within a set of ethical reflections and ultimately decisions to reduce the probability of an adverse outcome. What is new here is the clarification of response positive and response negative communication signals as a component of ethical decision- making, as well as the understanding that a romance follows a progression of steps. Because workplace relationships should be preserved regardless of the outcome of a personal affair, it is important that employees understand that clear communication signaling is necessary to move to the next step of the relationship. Employees can be trained to learn what is and what is not, response positive or response negative behaviors associated with each step of the relationship. Employees can also be trained to realize that continuous contact through digital communications may lead to the perception of a hostile work environment that may require organizational action. Relationships can also be seen as a stepwise progression so that employees understand at what point they can move forward versus retract their romantic initiatives.

\section{Communication Ethics Regarding the External Relationship: The Role of Human Resources}

Because social media technologies create dissonance between appropriate and inappropriate behaviors, human resource professionals also should train employees to clearly state response positive and response negative behaviors and interest. Training can also be provided so employees recognize the conditions under which social media contacts are considered acceptable, or not. For example, workers may be encouraged to text each other on work-related issues concerning lunch meetings, but not personal late at night romantic endeavors on a company provided cell phone. Employees should be reminded that use of company property, such as cell phones or computers, is discoverable in the eyes of the law, and inappropriate contacts will carry consequences.

The Communication Ethics Model of Workplace Romance reflects Jones's (1991) issue-contingent component of moral intensity to determine whether or not human resource professionals should intervene in the emerging romance. Bowes-Sperry and Powell (1999) proposed and tested Jones's model as a way of conceptualizing individual's reactions to social-sexual behavior at work, and found that according to the Jones (1991) model, two components of the moral intensity of the behavior-social consensus and magnitude of consequences-directly influenced observers reactions. When observers witnessed behavior by the initiator that appeared to have a greater effect on the target, and when they believed there was social consensus that most people would regard the behavior as sexual harassment, observers were more likely to take action. Human resource professionals are often called to discuss matters in the gray area when a coworker reports unseemly behavior between members of a couple, or when a report is made about potential adverse effects or consequences 
concerning performance or promotion. Organizational factors listed in the model such as group dynamics, authority figures, socialization, organizational policy, and the need for peer or human resource intervention should be evaluated. Similar to Rest's (1986) stages of ethical decision-making model, once an incident is disclosed or made known human resource professionals should at minimum engage both parties in the following topics of conversation:

1. What behaviors concerning social media inside and outside the office are not acceptable (Ex: That sending explicit pornographic photos to employees is not considered appropriate)

2. The reasons why such behaviors might constitute a form of harassment, if improperly used (Ex: That the sending of such images, either initially or subsequently, could be considered a harassing act, and may be viewed as illegal according to state statues concerning the dissemination of pornographic material)

3. That the continuation of such improper behaviors will lead to organizational consequences, such as disciplinary warnings, transfers, and/or termination of employment (Ex: That continued photo sharing will not be tolerated, and could lead to disciplinary action or termination of employment), and

4. That human resources professionals will be compelled to investigate any current or future claim of harassment that might take place through social media contacts inside or outside the office (Ex: That this action may require further investigation and possible legal counsel before determining organizational action and consequences.)

\section{Case Scenario \#5}

Consider this final case scenario. A female marketing director who recruits MBAs for a large financial firm became involved with a man who she hired into the firm. As part of her job responsibilities, she was to monitor the progress of each new hire to determine whether or not they were employable after a six-month trial period. Very often, she would take the new hires to lunch to discuss performance evaluations. When the romance initially blossomed, the woman assigned the man directly to her department to work on specialized marketing initiatives rather than a standard analyst position. Coworkers grew resentful of the special attention the woman boss was giving to the new hire, and wanted to find out if they were romantically involved. A female coworker in the marketing research area friended the new hire on his Facebook page, asked for his cell phone number, and tagged his FourSquare location at lunch. When one day both the female boss and the male new hire were tagged to a hotel during lunchtime outside of the office, word was spread that the two were having a romantic affair. However, both denied a romantic involvement and protested they were simply meeting a client in the hotel lobby. Coworkers searched for further evidence of a personal relationship on various social media platforms and discovered excessive commentary through Tumblr. The woman was called to the vice president's office for verification of the affair.

The Communication Ethics Model for Workplace Romance would suggest that while this situation would not necessarily meet the standard of the law for hostile work environment (unless more details become evident), human resources personnel should take an active communications role as an ethical imperative if the woman makes the situation known. Such a dialog would require both parties to attend a meeting facilitated by Human Resources to focus discussion communication on a set of ethical decisions that impact on office decorum.

We recommend a four-stage dialog, which would begin with the following discussion of intent and questioning of each party, separately and together:

\section{Fact-Gathering:}

- Describe your relationship and how it evolved to date.

II. Examination of Impacts:

- What has been the impact of this relationship on the other party's working relationship with you?

- What has been the impact of this relationship on other workers in your department?

III. Analysis:

- In the early stages of the relationship, was the response positive or negative to the initiation of the relationship?

- During the maintenance stage of the relationship, was the response positive or negative to continue and maintain the relationship?

- How has the relationship concluded?

IV. Discussion of Organizational Ethical Responses and Consequences:

- What are the ethics of this situation as it pertains to this firm? For each party?

- Is there moral and/or legal justification for action?

- What consequences should be levied for inappropriate behavior that creates a potentially hostile work environment?

Such a dialog would require both of the aggrieved parties as well as coworkers in the Marketing Department to attend a meeting facilitated by Human Resources to focus 
discussion communication on a set of ethical decisions that impact the work environment. The communication ethics dialog would probably result in a reprimand on the part of the coworker for spreading cyberspace gossip about the two parties, an open discussion with the two coworkers about whether or not a romance was initiated or not, and the organizational policies within the firm concerning a romantically involved direct reporting relationship.

As part of this discussion, employees need to be told:

1. What behaviors concerning social media inside and outside the office are not acceptable,

2. The reasons why such behaviors might constitute a form of harassment, if improperly used,

3. That the continuation of such improper behaviors will lead to organizational consequences, such as disciplinary warnings, transfers, and/or termination of employment,

4. That human resource professionals will be compelled to investigate any claim of harassment that might take place through social media contacts inside or outside the office.

A new legal concept that has arisen is the idea of love contracts (see Amaral 2006; Eidelhoch and Russell 1998; Tyler 2008) that should be signed by both parties once a romance is disclosed. A love contract specifies that the employer desires to avoid misunderstandings, actual or potential conflicts of interest, complaints of favoritism, possible claims of sexual harassment, and employee morale and dissension problems that can potentially result from romantic relationships (see Amaral 2006 for examples of fraternization policies and love contracts.) If used, such contracts should specify, according to the firm's ethical code of conduct, appropriate versus inappropriate social media contacts and consequences. The final outcome of the above communication discussion might be that a love contract is drafted that meets the needs of the organization as well as the privacy needs of both parties.

The goal of this model is to take the issue of workplace romance and frame it within a set of ethical reflections to enhance open communication dialog to reduce the probability of an adverse outcome leading to accusations of sexual harassment. By examining this issue as a matter of communication ethics rather than strictly as the legal standard, employees may attain a clearer understanding of when, where, and with whom they may be crossing the line and why. Human resource professionals can develop training programs with similar scenarios to the ones sprinkled throughout this article to help employees understand the difference between positive or negative intent and the organizational consequences of their behaviors associated with social media contacts outside the office that might spillover into working relationships inside the office. Legislating how and when employees contact each other outside the office is not the point. Focusing on what is appropriate behavior, and how it might impact the office environment and working relationships within that environment, should be the focus of such training programs.

Given the widespread availability of social media, and the propensity for office romances to turn into harassment, defining office decorum associated with workplace romance will continue to be an incommodious and troublesome ethical topic. This topic deserves much further ethical debate and academic and legal discussion, as the gray area of ethical conduct must be specified further for future accountability on the part of human resource professionals, business ethicists, and legal scholars. Human resource professionals should not put their hands up and ignore such social media contacts outside the office; instead there should be clear policies and these policies must be clearly communicated to specify appropriate versus inappropriate communication in the form of a romance as well as the proscriptions around the use of social media. Otherwise these situations will degenerate quickly and create a loss of productivity in the office, as well as issues of moral accountability and possible future legal ramifications for the firm at large.

\section{References}

Amaral, H. P. (2006). Workplace romance and fraternization policies. Schmidt Labor Research Center, Seminar Research Series 1, University of Rhode Island, 1-16, Appendices A-E Legal contract and letter, 1-8. Retrieved March 23, 2011 from http://www. uri.edu/research/lrc/research/papers/Amaral_Fraternization.pdf

Anderson, C. I., \& Hunsaker, P. L. (1985). Why there's romancing at the office and why it's everybody's problem. Personnel, 62(2), 57-63.

Argandona, A. (2011). Beyond contracts: Love in firms. Journal of Business Ethics, 99, 77-85. doi:10.1007/s10551-011-0750-z.

Baker, D. D., Terpstra, D. E., \& Larntz, K. (1990). The influence of individual characteristics and severity of harassing behavior on reactions to sexual harassment. Sex Roles, 22, 305-324.

Baxter, L. A., \& Akkoor, C. (2008). Aesthetic love and romantic love in close relationships. In K. G. Roberts \& R. C. Arnett (Eds.), Communication ethics: Between cosmopolitanism and provinciality (pp. 23-46). New York: Peter Lang Publishing, Inc.

Bowes-Sperry, L., \& Powell, G. N. (1999). Observers' reactions to social-sexual behavior at work: An ethical decision making perspective. Journal of Management, 25, 779-802.

Boyd, C. (2010). The debate over the prohibition of romance in the workplace. Journal of Business Ethics, 97, 325-338.

Broderick v Ruder. (1989). 685 F. Supp. 1269 (D.D. C.).

Career Builder.com. (2009). Annual office romance survey. Retrieved June 11, 2011, from http://www.careerbuilder.com/share/aboutus/ pressreleasesdetail. aspx $?$ id=pr481\&sd=2\%210\%2F $2009 \&$ ed $=12 \%$ 2F $31 \% 2 \mathrm{~F} 2009$

Cheney, G., May, S., \& Munishi, D. (2011). Encountering communication ethics in the contemporary world: Principles, people, and contexts. In G. Cheney, S. May, \& D. Munishi (Eds.), The handbook of communication ethics (pp. 1-14). New York: Routledge. 
Devine, I., \& Markiewicz, D. (1990). Cross-sex relationships at work and the impact of gender stereotypes. Journal of Business Ethics, 9, 333-338.

EEOC Annual Report. (2010). Enforcement and litigation statistics. Retrieved April 1, 2012 from http://www.eeoc.gov/eeoc/statistics/enforcement/index.cfm.

Eidelhoch, A. M., \& Russell, B. M. (1998). Consensual relationship agreements: One more weapon in the arsenal for fighting sexual harassment in the workplace. Preventative Law Reporter, 17(3), 21-23.

Ess, C. (2011). Ethical dimensions of new technology/media. In G. Cheney, S. May, \& D. Munishi (Eds.), The handbook of communication ethics (pp. 204-220). New York: Routledge.

Gutek, B. (1985). Sex and the workplace: The impact of sexual behavior and harassment on women, men, and organizations. San Francisco: Jossey-Bass.

Hotelling, K. (1991). Sexual harassment: A problem shielded by silence. Journal of Counseling and Development, 69, 497-501.

Johannesen, R. L. (2002). Ethics in human communication. Long Grove, IL: Waveland Press, Inc.

Johannesen, R. L., Valde, K. S., \& Whedbee, K. E. (2008). Ethics in human communication. Long Grove, IL: Waveland Press, Inc.

Jones v Keith. (2002). No.00-2741. 2002 U.S. Dist. LEXIS 3365 (D. Mn. Feb. 25, 2002).

Jones, T. M. (1991). Ethical decision making by individuals in organizations: An Issue-contingent model. Academy of Management Review, 16, 366-395.

Jones, T. M., \& Ryan, L. V. (1998). The effect of organizational forces on individual morality: Judgment, moral approbation, and behavior. Business Ethics Quarterly 8(3), 431-445.

Kelley, P. C., \& Elm, D. R. (2001). The effect of context on moral intensity of ethical issues: Revising Jones's (1991) issuecontingent model. Journal of Business Ethics, 48(2), 139-154.

King v Palmer. (1986). 778 F. 2nd 878 (D.C. Cir. 1985).

Knapp, D. E., Faley, R. H., Ekeberg, S. E., \& Dubois, C. L. (1997). Determinants of target responses to sexual harassment: A conceptual framework. Academy of Management Review, 22, 687-729.

Lenhardt, A. Purcell, K. Smith, A., \& Zickuhur, K. (2010). Social media and young adults. Pew Center for Internet and American Life (2010) Social Media and Young Adults Survey. Retrieved June 11, 2011 from http://www.pewinternet.org/Reports/2010/ Social-Media-and-Young-Adults.aspx

Littlejohn, S. W., \& Foss, K. A. (Eds.). (2009). Encyclopedia of communication theory (Vol. 1). Los Angeles: Sage Publications Inc.

Mainiero, L. A. (1986). A review and analysis of power dynamics in organizational romances. Academy of Management Review, 11, $750-762$.

Mainiero, L. A. (1989). Office romance: Love, power and sex in the workplace. New York: Rawson Associates.

Mainiero, L. A. (2005). On the ethics of office romance: Developing a moral compass for the workplace. In M. Mattis \& R. Burke (Eds.), Supporting women's career advancement (pp. 151-173). London: Edward Elgar Press.

McDonough v Smith. (2001). 270 B.R. 544 (D. Ma.2001).

McDonald, G., \& Pak, P. (1996). It's all fair in love and war and business: Cognitive philosophies in ethical decision making. Journal of Business Ethics, 15(9), 973-996.

McMahon, J. M., \& Harvey, R. J. (2006). An analysis of the factor structure of jones'moral intensity construct. Journal of Business Ethics, 64, 381-404.

Miceli, M. P., \& Near, J. P. (1992). Blowing the whistle: Organizational and legal implications for companies and employees. New York: Lexington.
Michelson, G., \& Mouly, V. S. (2002). You didn't hear it from us but...": Towards an understanding of rumour and gossip in organizations. Australian Journal of Management, 27, 57-66.

Miller (and Mackey-deceased) v Department of Corrections. (2005). 36 Cal. 4th 446, 465.

Monster.com. (2010). Romance in the workplace survey. Retrieved June 11, 2011 from http://hiring.monster.com $/ \mathrm{hr} / \mathrm{hr}$-bestpractices/workforce-management/improving-employee-relations/ romance-in-the-workplace.aspx

Morris, S., \& McDonald, R. A. (1995). The role of moral intensity in ethical decision-making: An empirical investigation. Journal of Business Ethics, 14(9), 725-726.

Neher, W. W., \& Sandin, P. J. (2007). Communicating ethically: Character, duties, Consequences and relationships. Boston: Pearson Education, Inc.

O’Leary-Kelly, A. M., \& Bowes-Sperry, L. (2001). Sexual harassment as unethical behavior: The role of moral intensity. Human Resource Management Review, 11, 73-92.

O'Leary-Kelly, A. M., Bowes-Sperry, L., Bates, C. A., \& Lean, E. R. (2009). Sexual harassment at work: A decade (plus) of progress. Journal of Management, 35(3), 503-536.

Parker-Pope, T. (2011). Digital flirting: Easy to do, and easy to get caught. The New York Times, Science Section, June 14, 4.

Pierce, C. A. (1998). Factors associated with participating in a romantic relationship in a work environment. Journal of Applied Social Psychology, 28, 1712-1730.

Pierce, C. A., \& Aguinis, H. (1997). Bridging the gap between romantic relationships and sexual harassment in organizations. Journal of Organizational Behavior, 18, 197-200.

Pierce, C. A., \& Aguinis, H. (2001). A framework for investigating the link between workplace romance and sexual harassment. Group and Organization Management, 26(2), 206-229.

Pierce, C. A., \& Aguinis, H. (2005). Legal standards, ethical standards, and responses to social-sexual conduct at work. Journal of Organizational Behavior, 26(6), 727-732.

Pierce, C. A., Broberg, B. J., McClure, J. R., \& Aguinis, H. (2004). Responding to sexual harassment complaints: Effects of a dissolved workplace romance on decision-making standards. Organizational Behavior and Human Decision Processes, 95(1), 66-82.

Pierce, C. A., Byrne, D., \& Aguinis, H. (1996). Attraction in organizations: A model of workplace romance. Journal of Organizational Behavior, 17, 5-32.

Planalp, S., \& Fitness, J. (2011). Interpersonal communication ethics. In G. Cheney, S. May, \& D. Munishi (Eds.), The handbook of communication ethics (pp. 135-147). New York: Routledge.

Powell, G. N., \& Foley, S. (1998). Something to talk about: Romantic relationships in organizational settings. Journal of Management, 24, 421-448.

Proxel v Gattis. (1996). 41 Cal. App. 4th 1626.

Quinn, R. (1977). Coping with cupid: The formation, impact, and management of romantic relationships in organizations. Administrative Science Quarterly, 22, 30-45.

Rest, J. R. (1986). Moral development: Advances in research and theory. New York: Praeger.

Schneider, K. T., Swan, S., \& Fitzgerald, L. F. (1997). Job-related and psychological effects of sexual harassment in the workplace: Empirical evidence from two organizations. Journal of Applied Psychology, 82, 401-415.

SHRM Society for Human Resource Management. (2002). Workplace romance survey. Alexandria, VA: SHRM Public Affairs Department.

SHRM Society for Human Resource Management. (2006). Workplace romance survey. SHRM/CareerJournal.com. January, 1-17. Retrieved March 23, 2011 from http://www.shrm.org/Research/ SurveyFindings/Articles/Documents/06-WorkplaceRomance PollFindings\%20(2).pdf 
Sias, P. M. (2009). Organizing relationships: Traditional and emerging perspectives on workplace relationships. Los Angeles: Sage Publications, Inc.

Stewart, J. (2011). A contribution to ethical theory and praxis. In G. Cheney, S. May, \& D. Munshi (Eds.), The Handbook of Communication Ethics. New York: Routledge.

Terpstra, D. E., \& Baker, D. D. (1992). Outcomes of federal court decisions on sexual harassment. Academy of Management Journal, 35, 181-190.
Tyler, K. (2008). Sign in the name of love: Can "love contracts" decrease an employer's litigation risks and keep office romances in check? HR Magazine, 53(2), 41-43.

Vault.com's. (2010). Office romance survey. Retrieved March 23, 2011 from http://www.vault.com/officeromancesurvey 
Reproduced with permission of the copyright owner. Further reproduction prohibited without permission. 